\title{
MICROMORPHOLOGY AND PEDOGENESIS OF MOUNTAINOUS INCEPTISOLS IN THE MANTIQUEIRA RANGE (MG)
}

\author{
Micromorfologia e pedogênese de Cambissolos altimontanos na \\ Serra da Mantiqueira (MG)
}

\author{
Leandro Campos Pinto ${ }^{1}$, Yuri Lopes Zinn², Carlos Rogério de Mello ${ }^{3}$, Phillip Ray Owens ${ }^{4}$, \\ Lloyd Darrell Norton ${ }^{5}$, Nilton Curi ${ }^{2}$
}

\begin{abstract}
Understanding soil formation processes across different landscapes is needed to predict how soil properties will respond to land use change. This study aimed to characterize mountainous Inceptisols (Cambisols) under high altitude subtropical climate in southeastern Brazil, by soil physical, chemical and micromorphological analyses, under native forest and pasture. The soil under pasture had a greater bulk density than under forest, resulting in a severe reduction of macroporosity. At two depths, coarse quartz grains are angular, suggesting absence of transportational processes, thus confirming an autochthonous pedogenesis from the underlying gneissic rock. Most feldspars were weathered beyond recognition, but mineral alteration was commonly seen across cleavage plans and edges of micas. The micromorphological results suggest an intermediate stage of mineral weathering and soil development, which is in accordance with properties expected to be found in Inceptisols.
\end{abstract}

Index terms: Soil formation; soil microstructure; land use change; forest soils.

\section{RESUMO}

Há a necessidade de se compreender os processos de formação do solo em diferentes paisagens para prever como as propriedades do solo irão responder às mudanças no uso do solo. Neste estudo, objetivou-se caracterizar Cambissolos em uma região montanhosa sob clima subtropical de altitude no Sudeste do Brasil, por meio de análises físicas, químicas e micromorfológicas do solo, sob mata nativa e pastagem. O solo sob pastagem apresentou maior densidade do solo do que sob mata, expressa pela intensa redução de macroporosidade na primeira condição. Em ambas as profundidades, os grãos de quartzo grosseiros são angulares, sugerindo ausência de quaisquer processos de transporte, confirmando, assim, uma pedogênese autóctone, a partir da rocha gnáissica subjacente. A maioria dos feldspatos se encontra intemperizada e não mais identificável, mas a alteração mineral é comumente vista ao longo de planos de clivagem e bordas de micas. Os resultados micromorfólogicos sugerem um estágio intermediário de intemperismo mineral e desenvolvimento do solo, o que está de acordo com as propriedades esperadas em Cambissolos.

Termos para indexação: Formação do solo; microestrutura do solo; mudança no uso da terra; solos florestais.

\section{INTRODUCTION}

Over the years, soil scientists have delineated concepts and models of soil formation to improve our knowledge of pedogenesis (Stockmann; Minasny; McBratney, 2014). Soil description, characterization and data interpretation must be undertaken within a perspective of its inherent association to local geology and geomorphology, helping to understand the distribution of different soils and the variability of their properties across the landscapes (Barbosa; Lacerda; Bilich, 2009). In subtropical humid regions, the high silt/clay ratio of the Inceptisols, coupled with small solum thickness (A + B horizons), and low natural soil fertility in mountainous relief make this an unstable and fragile system (Resende et al., 1988).

Mountainous soils in high altitude subtropical regions constitute unique and fragile environments, with highly endemic vegetation (altimountainous cloud forests) that are important refuges for animal and plant life (Simas et al., 2005). In Southeastern Brazil, the Mantiqueira Range is a $500 \mathrm{~km}$ long Archean rocky mass that borders three States and often reaches altitudes between 1,500 and 2,900 $\mathrm{m}$ a.s.1. This is one of the most important headwater regions in SE Brazil, although its steep slopes, abundant rainfall and shallow to moderately deep soils (Silva et al., 2014) causes a high potential risk of erosion and mass wasting. The distribution of soils in the Mantiqueira

\footnotetext{
1Universidade Federal de Lavras/UFLA - Departamento de Ciência do Solo/DCS - Cx. P. 3037 - $37200-000$ - Lavras - MG - Brasil leandcampos@yahoo.com.br

${ }^{2}$ Universidade Federal de Lavras/UFLA - Departamento de Ciência do Solo/DCS - Lavras - MG - Brasil

3Universidade Federal de Lavras/UFLA - Departamento de Engenharia/DEG - Lavras - MG - Brasil

${ }^{4}$ Purdue University - Department of Agronomy - West Lafayette - IN - USA

${ }^{5}$ Purdue University - USDA - ARS National Soil Erosion Research Laboratory - West Lafayette - IN - USA

Received in april 29, 2015 and approved in may 22, 2015
} 
Range is mainly influenced by lithology (Dias et al., 2003) and topography. The steep slopes help to promote accelerated erosion, and a rather resistant to weathering gneissic bedrock are both factors leading to the presence of Inceptisols (Cambisols) (Santos et al., 2010). According to Benites et al. (2003), under native forests these soils are relatively stable, but after land use changes to pastures, they become rapidly degraded, chiefly by erosion, loss of organic matter and natural fertility depletion.

According to Buol et al. (2011), relatively few studies have focused on Inceptisols, although this presents an opportunity to study the weathering of minerals and better understanding the early stages of many pedogenic processes. Thus, the aim of this study was to employ soil micromorphology to characterize Inceptisols in the Mantiqueira Range (MG), improving the understanding of how soil genesis proceeds under such conditions.

\section{MATERIAL AND METHODS}

\section{Site description}

The Lavrinha Creek watershed (Figure 1) is an experimental area in which many hydrologic, climatic and soil investigations have been carried out since 2004 (Mello et al., 2011). It is located in the southeastern part of the State of Minas Gerais, Brazil, within the Mantiqueira Range physiographical region. A digital elevation model based on a 1:50,000 chart and GPS data was built in 30 vs. $30 \mathrm{~m}$ pixels and shown in Figure 1. The watershed has an area of 676 ha, with elevations between 1,137 and $1,733 \mathrm{~m}$ a.s.1.

According to RADAMBRASIL (1983) and Soares et al. (1994), the Andrelândia Group is the most common lithological unit in the southern portion of the Mantiqueira Range. In the studied watershed, the main parent material is Neoproterozoic gneiss (CETEC, 1983; Menezes et al., 2009). Soils are predominantly shallow in the highest parts of the Mantiqueira Range (Benites et al., 2005). Inceptisols (Cambisols) are the main soils, covering $92 \%$ of the watershed area, with depths ranging from 0.70 to 1.20 $\mathrm{m}$, including the $\mathrm{C}$ horizon (Menezes et al., 2009). These soils are most often used as grazing lands, mainly limited by the relief, high stone content, low natural fertility, and surface crusting, restricting permeability and promoting erosion (Giarola et al., 1997).

According to Mello et al. (2012), local climate is super-humid by the Thornthwaite classification, meaning a highly positive water balance during the whole year. Alternatively, local climate can be classified as Cwb (rainy temperate or altitude subtropical) type by the Köppen classification, with cool winters, with lesser rainfall than the summer. The mean annual precipitation ranged from $1,841 \mathrm{~mm}$ to $2,756 \mathrm{~mm}$ (2006-2012), with $c a$. 88.3\% between September and March. Mean annual temperature is $\mathrm{ca} .17^{\circ} \mathrm{C}$, with average low and high temperatures of $10{ }^{\circ} \mathrm{C}$ and $23{ }^{\circ} \mathrm{C}$, respectively. According to Reboita et al. (2010), most rainfall events are associated with cold fronts throughout the year. However, the South Atlantic Anticyclone, a high-pressure zone that precludes cloud formation, leads to a characteristic dry period during the winter and occasional winter frosts at high elevations.

Approximately $33 \%$ of the watershed area is covered by pastures, 5\% are under Eucalyptus grandis plantations, and the rest is under native forest. The extensive pastures mainly comprise Brachiaria decumbens and are currently degraded, with weed invasion and soil surface sealing. For this study, soil samples were taken only from the two main land uses, namely native forest and pasture. The sampled location under forest presents an average slope of 45\% (Ávila et al., 2014), whereas, under pasture (Figure 1) presents very rugged relief class $(20-45 \%)$ in $67.2 \%$ of area and mountainous $(45-75 \%)$ in $10.9 \%$ of area (Oliveira et al., 2014).

\section{Soil analyses}

Disturbed and undisturbed soil samples were collected from pit walls at $0-20$ and $20-50 \mathrm{~cm}$ depths. Particle size distribution was determined by the hydrometer method (Gee; Bauder, 1986), whereas, bulk density was determined by the core method (Blake; Hartge, 1986). Soil organic carbon was determined by the Cantarella, Quaggio and van Raij (2001) method, whereas, soil pH was measured in a 1:2.5 soil/water suspension.

Undisturbed samples for soil micromorphology studies were collected at the same depths (0-20 and 20-50 $\mathrm{cm})$ with a Kubiena box. These samples were air-dried for several weeks, and subsequently dried in an oven at $40{ }^{\circ} \mathrm{C}$, $60^{\circ} \mathrm{C}$ and $100^{\circ} \mathrm{C}$, to minimize cracking due to rapid drying. The samples were then impregnated with an epoxy resin and de-aerated under vacuum (Castro et al., 2003) for three days to minimize air bubbles, and then heated at $100{ }^{\circ} \mathrm{C}$ for 4 hours, and $140^{\circ} \mathrm{C}$ for 4 hours for hardening and curing. The hardened resin blocks were cut with a diamond saw, polished on rotating corundum paper and mounted onto glass slides with de-aerated Hillquist ${ }^{\mathbb{B}}$ epoxy resin 7A/3B, heated for $1 \mathrm{~min}$. at $105^{\circ} \mathrm{C}$. Finally, the mounted blocks were sectioned and polished to the ideal thickness of $30 \mu \mathrm{m}$ for micromorphological analysis, as recommended by Murphy (1986), and analyzed with a petrographic microscope. 


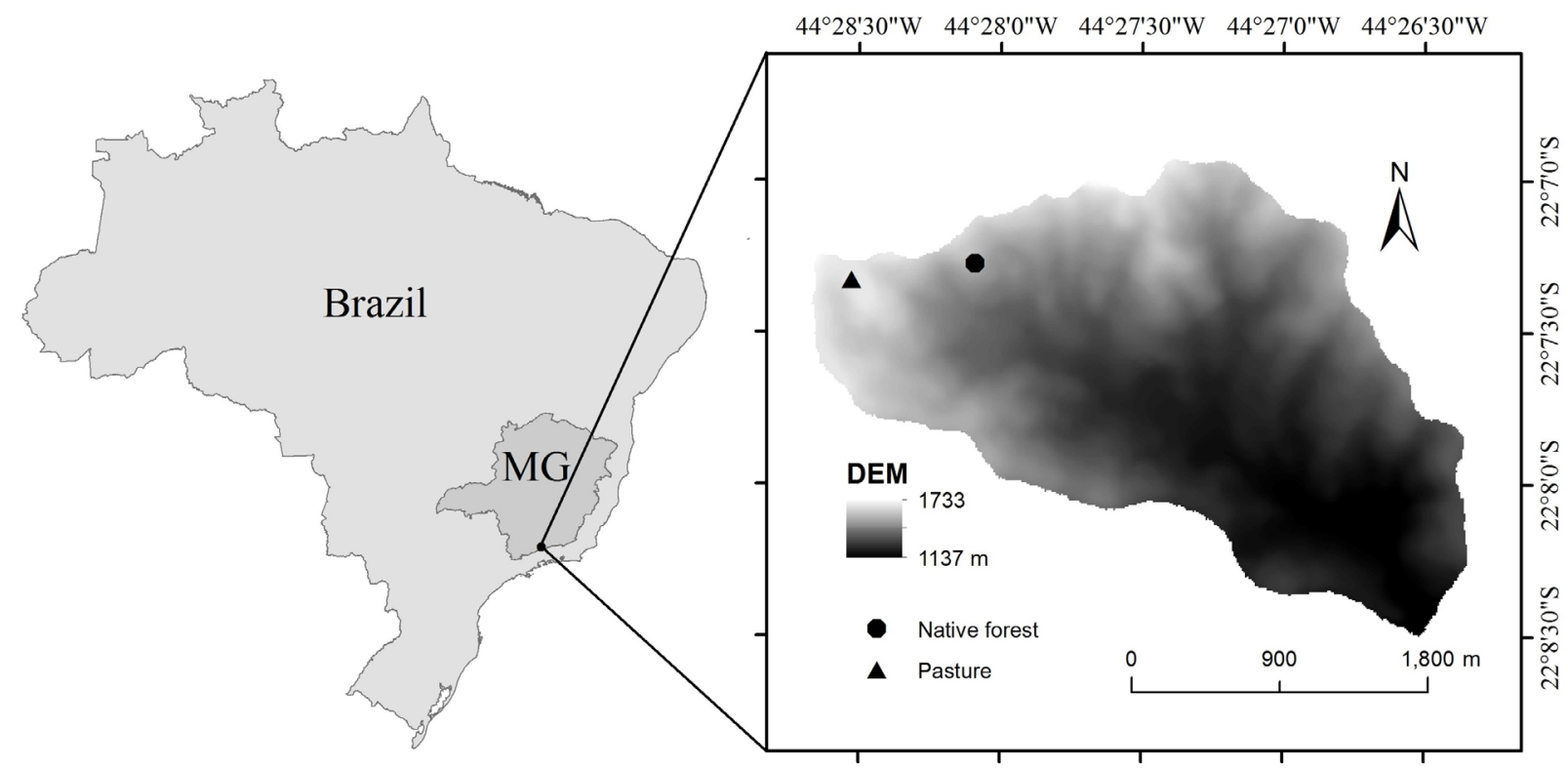

Figure 1: The study watershed in Southeastern Minas Gerais, Brazil.

\section{RESULTS AND DISCUSSION}

\section{Soil characterization}

The physical and chemical characteristics of the studied soils are presented in Table 1.

Silt/clay ratios are relatively high, suggesting an intermediate degree of rock weathering, which are associated with the presence of semi-weathered minerals modified by steep reliefs under a humid climate. Soil organic matter (SOM) contents under native forest are high at the $0-20 \mathrm{~cm}$ depth, and $\mathrm{pH}$ is accordingly very low (Table 1$)$. Such conditions are favored by local high precipitation $(\sim 2,000 \mathrm{~mm}$ per year) and mildly cool temperatures, even during the summer (Mello et al., 2012). There were losses of $\sim 50 \%$ and of $\sim 28 \%$ of SOM contents at the $0-20$ and $20-50 \mathrm{~cm}$ depths, respectively, upon land use change to pasture. In fact, the forest floor accumulates a substantial litter layer approximately $15 \mathrm{~cm}$-thick cm above mineral soil (Santos et al., 2013), protecting against soil erosion and degradation (Alvarenga et al., 2012). The soil under pasture had greater bulk density compared to the soil under forest, which can be ascribed to the compaction (Biggs; Dunne; Muraoka, 2006) and a decrease in SOM. The increase in bulk density at the $0-20 \mathrm{~cm}$ depth reported here is much greater than the average increase of $14 \%$ reported after clearing of native vegetation in the tropics (Don;
Schumacher; Freibauer, 2011). In the pasture area, erosion resulted in some areas with a thin (about $40 \mathrm{~cm}$ ) solum (A+B horizon) depth (Menezes et al., 2014), particularly on the steepest slopes.

\section{Soil micromorphology}

In both soils and depths, coarse quartz grains are angular (Figure 2), suggesting an absence of transportation processes or long-weathering time, thus confirming an autochthonous pedogenesis, i.e. soils were formed in situ and the pedogenesis/erosion rate is limited by the mountainous conditions. Furthermore, the generally elongate shape of quartz grains is in accordance with mid- to high-grade metamorphic rocks, namely orthogneiss.

Table 2 presents the porosity and microstructure features of Inceptisol under forest and pasture.

Abundant packing porosity is apparent at the $0-20 \mathrm{~cm}$ depth of the soil under native forest, amid a complex microstructure of moderately developed granular and subangular blocky type (Figure 2A and Table 2). Accordingly, abundant roots and faecal pellets indicate high biological activity at this depth. At the $20-50 \mathrm{~cm}$ depth, porosity is much lower and the subangular blocky microstructure is more developed, separated and partially accommodated in the presence of planar pores, and granules are absent (Figure 2B), in accordance with the morphological description in the field. 
Table 1: Soil physical and chemical properties of the studied Inceptisols (Cambisols).

\begin{tabular}{|c|c|c|c|c|c|c|c|}
\hline $\begin{array}{l}\text { Depth } \\
(\mathrm{cm})\end{array}$ & Clay & Coarse Sand & $\begin{array}{l}\text { Fine Sand } \\
\ldots . .(\%) \ldots \ldots . . .\end{array}$ & $\begin{array}{l}\text { Silt } \\
\ldots \ldots \ldots \ldots \ldots . . .\end{array}$ & SOM & $\mathrm{pH}$ & $\begin{array}{c}\text { Bulk density } \\
\left(\mathrm{kg} \mathrm{dm}^{-3}\right)\end{array}$ \\
\hline $0-20_{F}$ & 35 & 28 & 20 & 17 & 9.2 & 3.3 & 0.75 \\
\hline $20-50_{\mathrm{F}}$ & 29 & 29 & 20 & 22 & 4 & 4.2 & 0.93 \\
\hline $0-20_{\mathrm{P}}$ & 32 & 38 & 16 & 14 & 4.6 & 4.6 & 1.03 \\
\hline $20-50_{P}$ & 34 & 23 & 18 & 25 & 2.9 & 4.4 & 1.15 \\
\hline
\end{tabular}

Note: F (soil under native forest); P (soil under pasture); SOM (soil organic matter).
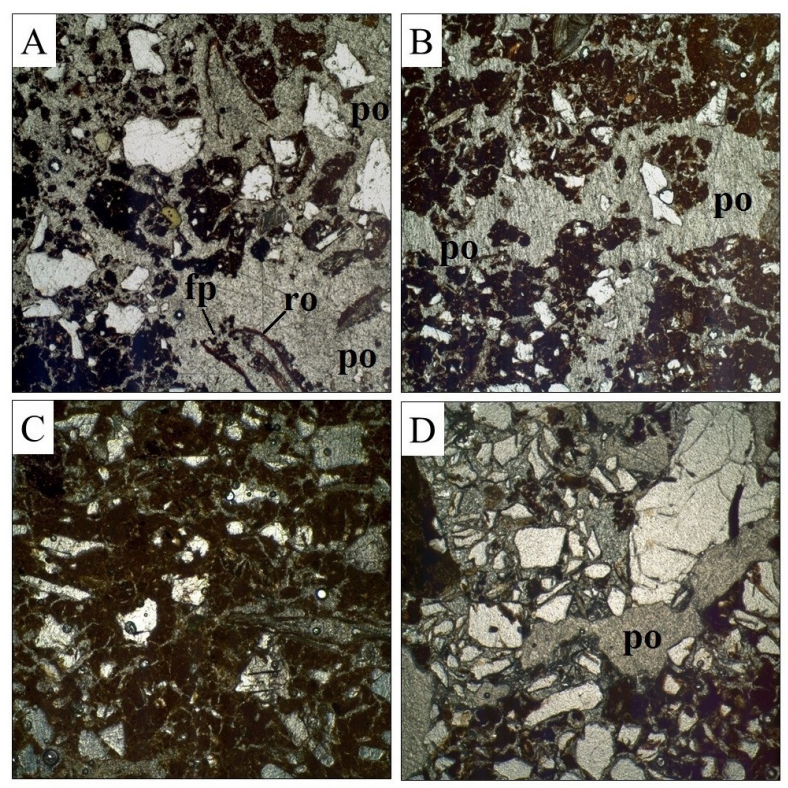

Figure 2: Thin sections of soils under native forest at 0-20 $\mathrm{cm} \mathrm{(A)} \mathrm{and} \mathrm{20-50} \mathrm{cm}$ depths (B), and under pasture at $0-20 \mathrm{~cm}(\mathrm{C})$ and $20-50 \mathrm{~cm}(\mathrm{D})$ depths. ro: roots; fp: faecal pellets, and po: pores. Frame length is $2.7 \mathrm{~mm}$. All images are under plane-polarized light.

In contrast, the soil under pasture $(0-20 \mathrm{~cm})$ presents a much closer-packed, blocky microstructure and much lower porosity (Figure 2C), in agreement with the increase in bulk density value (Table 1 ). At the $20-50 \mathrm{~cm}$ depth, the apparent accordance among coarse grain surfaces (Figure 2D), mainly along planes of weakness (Frazier; Graham, 2000), suggests a relatively recent fragmentation of the parent material. Such evidence supports the idea that erosion has made the weathering front closer to the soil surface, i.e., promoting soil rejuvenation.
Table 2: Porosity and microstructure features of Inceptisols under native forest and pasture.

\begin{tabular}{cll}
\hline $\begin{array}{c}\text { Inceptisol } \\
\text { (Cambisol) }\end{array}$ & \multicolumn{1}{c}{$0-20 \mathrm{~cm}$} & \multicolumn{1}{c}{$20-50 \mathrm{~cm}$} \\
\hline Under native & $\begin{array}{l}\text { Packing porosity; } \\
\text { forest }\end{array}$ & $\begin{array}{l}\text { Porosity is much } \\
\text { lower; subangular } \\
\text { microstructure } \\
\text { of moderately } \\
\text { developed granular } \\
\text { and subangular } \\
\text { blocky type }\end{array}$ \\
microstructure \\
Under pasture & $\begin{array}{l}\text { Closer-packed } \\
\text { and much lower } \\
\text { porosity; blocky } \\
\text { microstructure }\end{array}$ & $\begin{array}{l}\text { Coarse grain } \\
\text { surfaces }\end{array}$ \\
\hline
\end{tabular}

Intact feldspar grains were not observed, although expected in mountainous soils forming on gneissic rock, as noted by Borrelli et al. (2012) and Le Pera et al. (2001), among others. It is likely that most feldspars were already weathered into grayish, grainy alteromorph masses visible in some thin sections (Figures 3 and 5), in a pattern termed "microfractured" by Borrelli et al. (2012). Such information is reinforced by brownish clay domains, probably neoformed, visible on both images. However, the mineral alteration most commonly visible is on the basal and edge surfaces of coarse muscovite grains. Under planar polarized light (Figure 3A), the inner parts of muscovite domains appear colorless, with their basal cleavages visible, at times in neatly angular exfoliation. Nevertheless, the outer basal or edge surfaces, in contact with soil or rock fragments, present yellowish to brownish colors, representing the onset of alteration to kaolinite (Stoops, 2003) or hydroxi-interlayered vermiculite (Thompson; Ukrainczyk, 2002), as well as some intrusion by organic matter and/or Fe oxides. The mineralogy of the 
clay fraction of the B horizon of this soil reveals $62.4 \%$ of kaolinite and $32.7 \%$ of gibbsite, in agreement with its young-stage development and supports the muscovite $\rightarrow$ kaolinite and biotite $\rightarrow$ gibbsite main transformations. Under crossed polars, such alteration is visible by weak, first-order interference (yellowish) colors contrasting strongly with the high-interference (iridescent) colors of unaltered muscovite (Figure 3B). The same occurs for biotite, which however shows yellow to green colors under plane polar light (Figure 4A) and high interference colors under crossed polars (Figure 4B). As expected for Febearing micas, impregnation by $\mathrm{Fe}$-oxides on edge surfaces and in between cleavage plans of biotites (Figure 4) are more prevalent than for muscovites (Figure 3). Similar results were presented by Oliveira et al. (2008).
Weathered rock fragments are commonly interspersed within the soil matrix as gravels. Figure 5 shows a gneiss fragment, in which the core is composed by welded, elongated quartz grains (Qz) impregnated with an opaque mineral (om, probably a primary $\mathrm{Fe}$ oxide), and a brown, unknown mineral. Most interestingly, the surrounding grayish mass exhibits abundant intragranular microcracks typical of heavily altered feldspars, with abundant clay masses (cl), probably neoformed but also deposited as pore coatings. This can be considered prima facies evidence of clay formation from the local parent material, i.e., of an autochtonous soil genesis. The clay has not been translocated and layering is not apparent, therefore, warranting classification of Inceptisols.

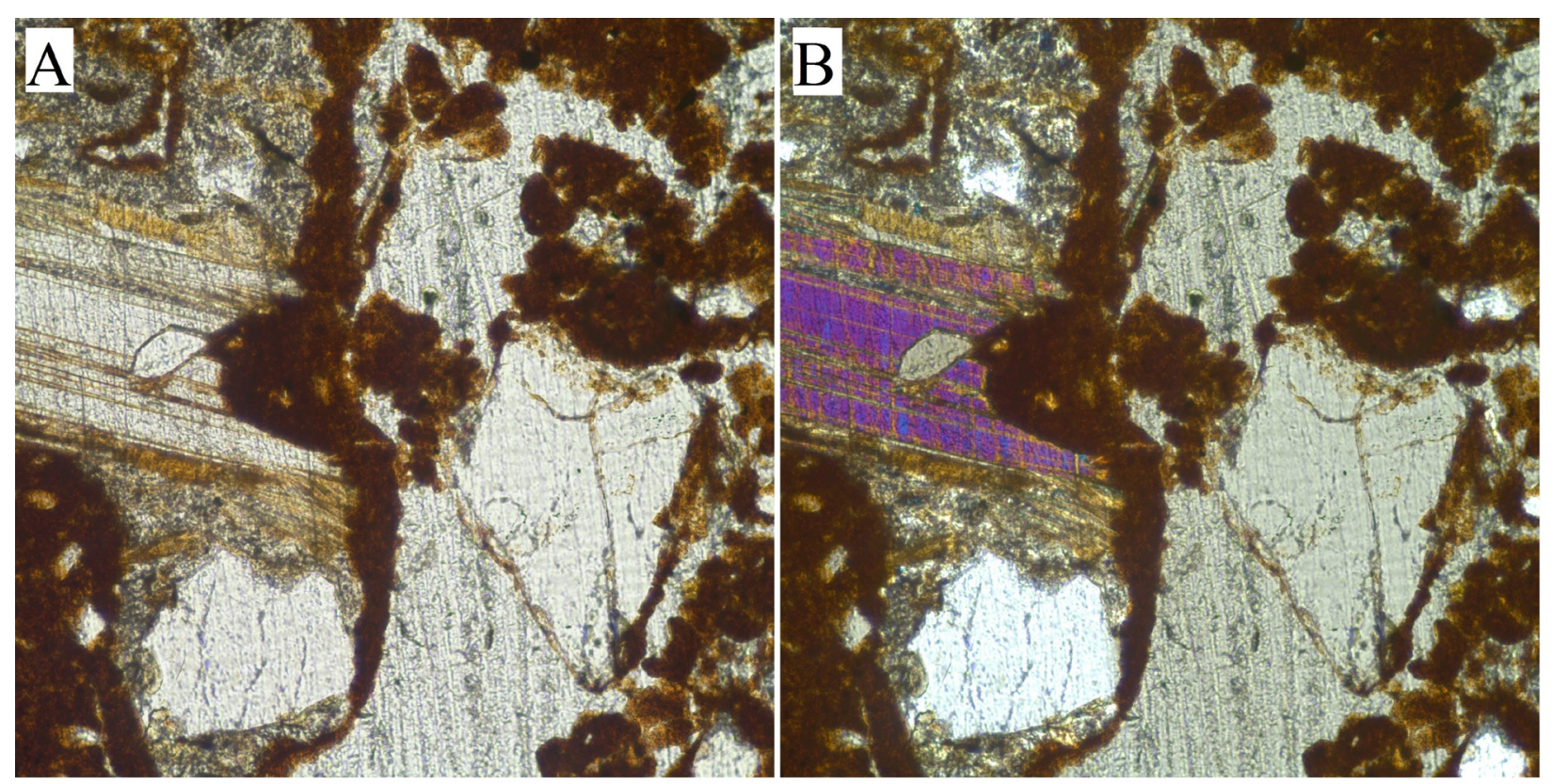

Figure 3: Thin sections of muscovite weathering, $20-50 \mathrm{~cm}$ depth. A) under planar polarized light; B) partially crossed polarized light. Frames are $0.5 \mathrm{~mm}$ wide. Note exfoliating cleavage of muscovite (lower basal surface) and microfractured feldspar alteromorph with clay masses (upper left). 


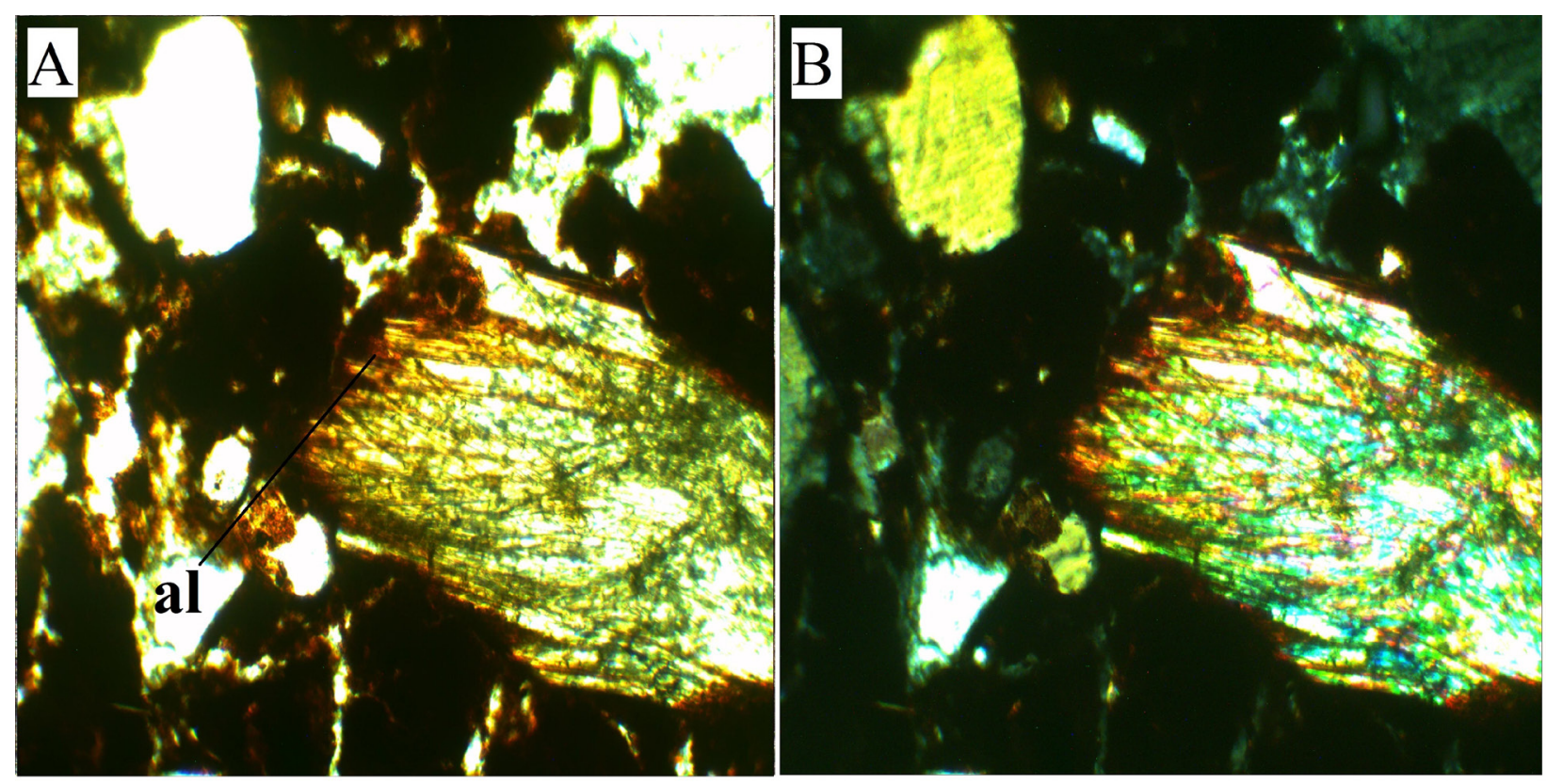

Figure 4: Thin sections of mineral weathering of a biotite domain, $20-50 \mathrm{~cm}$ depth. A) under planar polarized light; B) under cross-polarized light. al (alteration in terminal edges and basal cleavage surfaces). Frames are $0.9 \mathrm{~mm}$ wide.

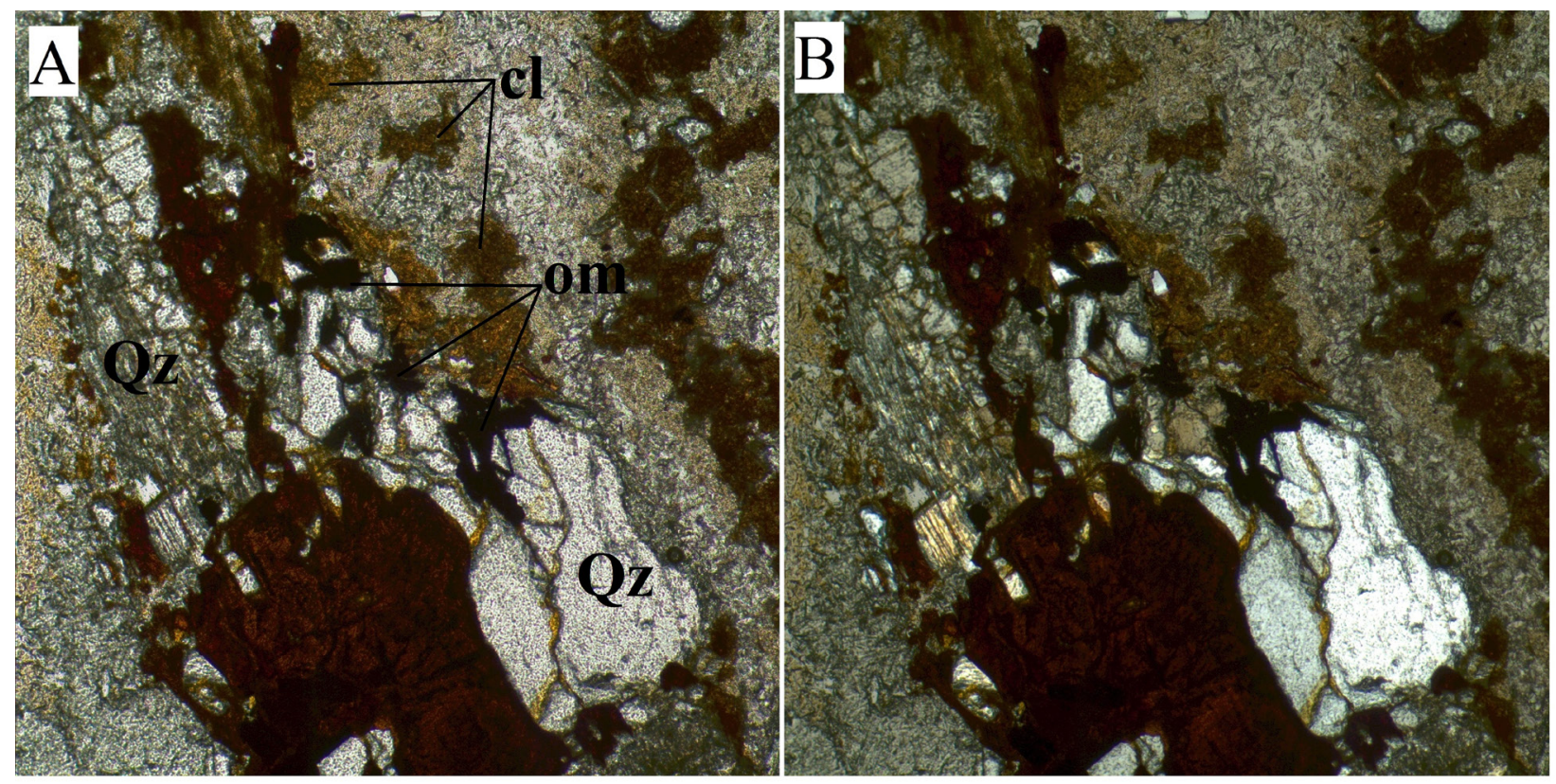

Figure 5: Weathered rock fragment, 20-50 cm depth. A) under planar polarized light; B) under cross-polarized light. The microgranular, gray mass surrounding the core is probably a highly altered feldspar. cl (neoformed clay masses); om (opaque mineral); Qz (quartz). Frames are $0.9 \mathrm{~mm}$ wide. 


\section{CONCLUSIONS}

The micromorphological results reveal an intermediate stage of mineral weathering and soil development, which is in exact accordance with properties expected to be found in mountainous Inceptisols (Cambisols). More specifically, such conclusions were grounded on: a) clay contents within the medium texture class, suggesting an intermediate degree of pedoplasmation; b) advanced stage of weathering of feldspars, the most common rock components; c) considerable presence of micas, not only muscovite but also biotite in the coarse material; d) visible alteration of such micas into secondary phyllosilicates, mostly kaolinite, a mineral typical of subtropical soils in young-stage development. No evidence of translocation was found for the neoformed clays thus supporting the classification of these soils as Inceptisols.

\section{REFERENCES}

ALVARENGA, C.C. et al. Índice de qualidade do solo associado à recarga de água subterrânea (IQS RA) na Bacia Hidrográfica do Alto Rio Grande, MG. Revista Brasileira de Ciência do Solo. 36:1608-1619, 2012.

ÁVILA, L.F. et al. Partição da precipitação pluvial em uma microbacia hidrográfica ocupada por Mata Atlântica na Serra da Mantiqueira, MG. Ciência Florestal. 24(3):583-595, 2014.

BARBOSA, I.O; LACERDA, M.P.C.; BILICH, M.R. Relações pedomorfogeológicas nas chapadas elevadas do Distrito Federal. Revista Brasileira de Ciência do Solo. 33(5):1373-1383, 2009.

BENITES, V.M. et al. Solos e vegetação nos Complexos Rupestres de Altitude da Mantiqueira e do Espinhaço. Revista Floresta e Ambiente. 10(1):76-85, 2003.

BENITES, V. M. et al. Properties of black soil humic acids from high altitude rock complexes in Brazil. Geoderma. 127:104-113, 2005.

BIGGS, T.W.; DUNNE, T.; MURAOKA, T. Transport of water, solutes, and nutrients from a pasture Hillslope, Southwestern Brazilian Amazon. Hydrological Processes. 20(12):2527-2547, 2006.

BLAKE, G.R.; HARTGE, K.H. Bulk density. In: KLUTE, A. Methods of soil analysis. Madison: American Society of Agronomy, Soil Science Society of America, 1986. p.363-375.
BORRELLI, L. et al. Minero-petrographical features of weathering profiles in Calabria, southern Italy. Catena. 92:196-207, 2012.

BUOL, S.W. et al. Soil genesis and classification. John Wiley and Sons, New York, 2011. 543p.

CANTARELLA, H.; QUAGGIO, J.A.; VAN RAIJ, B. Determinação da matéria orgânica. In: RAIJ, B. et al. Análise química para avaliação da fertilidade de solos tropicais. Campinas, Instituto Agronômico de Campinas, 2001. p.173-180.

CASTRO, S.S. et al. Micromorfologia do solo: bases e aplicações. In: CURI, N. et al. Tópicos em ciência do solo. Viçosa, MG, Sociedade Brasileira de Ciência do Solo, 2003. v. 3, p.107-164.

CENTRO TECNOLÓGICO DE MINAS GERAIS CETEC. Diagnóstico Ambiental do Estado de Minas Gerais. Belo Horizonte: CETEC, 1983.

DIAS, H.C.T. et al. Caracterização de solos altimontanos em dois transectos no Parque Estadual do Ibitipoca (MG). Revista Brasileira de Ciência do Solo. 27(3):469-481, 2003.

DON, A.; SCHUMACHER, J.; FREIBAUER, A. Impact of tropical land-use change on soil organic carbon stocks - a meta-analysis. Global Change Biology. 17(4):1658-1670, 2011.

GEE, G.W.; BAUDER, J.W. Particle-size analysis. In: KLUTE, A. Methods of soil analysis: physical and mineralogical methods. Madison: American Society of Agronomy, Soil Science Society of America, 1986, p.383-411.

FRAZIER, C.S.; GRAHAM, R.C. Pedogenic transformation of fractured granitic bedrock, southern California. Soil Science Society of America Journal. 64(6):2057-2069, 2000.

GIAROLA, M.F.B. et al. Solos da região sob influência do reservatório da hidrelétrica de Itutinga/Camargos (MG): perspectiva ambiental. Belo Horizonte: CEMIG, 1997. 101p.

LE PERA, E. et al. Weathering of gneiss in Calabria, Southern Italy. Catena. 42:1-15, 2001. 
MELLO, C.R. et al. Spatial distribution of top soil water content in an experimental catchment of Southeast Brazil. Scientia Agricola. 68:265-393, 2011.

MELLO, C.R. et al. Sea surface temperature (SST) and rainfall erosivity in the Upper Grande River Basin, Southeast Brazil. Ciência e Agrotecnologia. 36(1):5359, 2012.

MENEZES, M.D. et al. Dinâmica hidrológica de duas nascentes, associada ao uso do solo, características pedológicas e atributos físico-hídricos na subbacia hidrográfica do Ribeirão Lavrinha-Serra da Mantiqueira (MG). Scientia Forestalis. 37(82):175184, 2009.

MENEZES, M.D. et al. Solum depth spatial prediction comparing conventional with knowledge-based digital soil mapping approaches. Scientia Agricola. 71(4):316$323,2014$.

MURPHY, C.P. Thin section preparation of soils and sediments. Berkhamsted: AB Academic Publishers, 1986. 149p.

OLIVEIRA, L. B. et al. Micromorfologia e gênese de Luvissolos e Planossolos desenvolvidos de rochas metamórficas no semi-árido brasileiro. Revista

Brasileira de Ciência do Solo. 32(6):2407-2423, 2008.

OLIVEIRA, A.S. et al . Stream flow regime of springs in the Mantiqueira Mountain Range region, Minas Gerais State. Cerne. 20(3):343-349, 2014.

\section{RADAMBRASIL. Projeto RADAMBASIL:}

Levantamento de recursos naturais, folha SF. 23/24. Rio de Janeiro, 1983. p.775.

REBOITA, M.S. et al. Regimes de precipitação na América do Sul: uma revisão bibliográfica. Revista Brasileira de Meteorologia. 25:185-204, 2010.
RESENDE, M.; CURI, N.; SANTANA, D.P. Pedologia e fertilidade do solo: Interações e aplicações. Brasília, MEC/ESAL/POTAFOS, 1988. 81p.

SANTOS, A.C. et al. Gênese e classificação de solos numa topossequência no ambiente de Mar de Morros do Médio Vale do Paraíba do Sul, RJ. Revista Brasileira Ciência do Solo. 34(4):1297-1314, 2010.

SANTOS, M.C.N. et al. Spatial continuity of soil attributes in an Atlantic Forest remnant in the Mantiqueira Range, MG. Ciência e Agrotecnologia. 37(1):68-77, 2013.

SILVA, S.H.G. et al. A technique for low cost soil mapping and validation using expert knowledge on a watershed in Minas Gerais, Brazil. Soil Science Society of America Journal. 78(4):1310-1319, 2014.

SIMAS, F.N.B. et al. Chemistry, mineralogy and micropedology of highland soils on crystalline rocks of Serra da Mantiqueira, southeastern Brazil. Geoderma. 125(3-4):187-201, 2005.

SOARES, A. C. P. et al. Nota explicativa dos mapas geológico, metalogenético e de ocorrência minerais do Estado de Minas Gerais. Belo Horizonte: COMIG, 1994. 97 p.

STOCKMANN, U.; MINASNY, B.; MCBRATNEY, A.B. How fast does soil grow? Geoderma. 216:48-61, 2014.

STOOPS, G. Guidelines for analysis and description of soil and regolith thin sections. Madison: Soil Science Society of America, 2003. 184p.

THOMPSON, M.L.; UKRAINCZYK, L. Micas. In: DIXON, J.B.; SCHULZE, D.G. Soil mineralogy with environmental applications. Madison, Soil Science Society of America, 2002. p.431-466. 